\title{
Ecological Characteristics of Groundwater in Rural Areas of the Karaganda Region
}

\author{
Samal Shamshedenova', Raikhan Beisenova', Zhanar Rakhymzhan', \\ Zhanat Zhaznaeva ${ }^{2}$, Nazym Syzdykova ${ }^{3}$, Rumiya Tazitdinova ${ }^{4 *}$, Marat Khanturin ${ }^{1}$ \\ 1 L.N. Gumilyov National Eurasian University, 010000, Nur-Sultan, Kazakhstan \\ 2 S. Amanzholov East Kazakhstan State University, 070020, Ust-Kamenogorsk, Kazakhstan \\ 3 E. A. Buketov Karaganda State University, 100028, Karaganda, Kazakhstan \\ 4 Sh. Ualikhanov Kokshetau State University, 020000, Kokshetau, Kazakhstan \\ * Corresponding author's e-mail: irm85@mail.ru
}

\begin{abstract}
In this article, the purpose of the research was to study the ecological characteristics of groundwater and central water supply used for drinking and economic activity of the Kievka village. The hydrochemical indicators of the samples were determined with conventional methods, and performed on 16 indicators: $\mathrm{pH}$, electrical conductivity, suspended solids, dry residue, chlorides, sulfates, phosphates, total hardness, sodium, ammonium nitrogen, nitrites, nitrates, chemical oxygen consumption (COD), anionic surfactants (APAS), total iron, and manganese. While assessing the hydrochemical state of drinking water in the village of Kievka, it can be noted the "Altyn-dan" kindergarten and the Kiev secondary school No. 3, exceed the MAC which is determined by certain indicators. As a result of microbiological studies of the water samples from the village of Kievka, it was revealed that the total microbial number is normal. It was determined that a different number of fungi and actinomycites were present in all samples. At the initial concentration, a large concentration of fungi was observed in all samples.
\end{abstract}

Keywords: drinking water, water quality, bacterial pollution, groundwater, environmental characteristics.

\section{INTRODUCTION}

Groundwater is usually a safe and reliable source of drinking water in many developing countries, especially in rural areas. The maintenance and protection of groundwater quality is of great importance as well as widely studied. Rural areas depend on groundwater as an important water resource. Although groundwater is less susceptible to pollution than surface water, local geology, lack of adequate sanitation and other factors can affect the water quality. Bacterial contamination raised concerns about the possibility of similar contamination in groundwater. The main processes controlling the quality of groundwater at the village level and the potential threat to human health were also studied (Brindha et al., 2017).
Groundwater depletion is a long-term decline in water levels, which is the expected result of water extraction from the country, facing depletion of groundwater throughout the world (Konikow \& Kendy, 2005). The gradual deterioration of the quality of surface (river and reservoir) water caused by many anthropogenic factors, including rapid urbanization, unplanned industrialization, disposal of household waste and agricultural runoff, led to a shortage of fresh water (Mukherjee et al., 2008; Singh, Tewary \& Sinha, 2011; Yadav et al., 2012; Kumar et al., 2017).

It was reported that $90 \%$ of the fresh water extracted from the underground sources is consumed in the irrigation practice; therefore, the quality of water directly affects the health of crops (Shiklomanov, 2000; Scanlon, Reedy \& Tachovsky, 2007; Raju, Ram \& Dey, 2009). 
Groundwater is the most important because of the need for drinking water, since it is the main source of drinking water in most areas (Singh, Tewary \& Sinha, 2011).

The Department of State Sanitary and Epidemiological Surveillance of the Nurinsky district conducts the planned sanitary-epidemiological control of the centralized water supply to the villages of Kievka, Karaganda oblast. Every month, a branch of the Center for Sanitary and Epidemiological Expertise of the Karaganda Region conducts the bacteriological and sanitary-chemical studies of the water in Kievka. The quality of water of the centralized water supply system in Kievka corresponds in all parameters to the Sanitary Regulations No. 554 dated July 28, 2010 "Sanitary and epidemiological requirements for water sources, household water supply and places of cultural water use and safety of water bodies".

The aim of our research was to study the ecological characteristics of groundwater and central water supply used for drinking and economic activities of the Kievka village.

\section{MATERIALS AND METHODS}

The water samples were taken from industrial and drinking water from several points of Kievka village.

For the hydrochemical and microbiological studies, the samples were taken from 6 points: No. 1 from an autonomous school well; No. 2 of the street column in the west of the village, where the beginning of the route; No. 3 from the crane of the Kiev secondary school No. 3; No. 4 from the crane of the "Altyn-dan" kindergarten; No. 5 from columns near the school from the east, at the beginning of the central water supply; Column No. 6 near the school from the west, at the end of the central water supply (see Table 1).
The hydrochemical indicators of the samples were determined with conventional methods, and performed on 16 indicators: $\mathrm{pH}$, electrical conductivity, suspended matter, dry residue, chlorides, sulfates, phosphates, total hardness, sodium, ammonium nitrogen, nitrites, nitrates, chemical oxygen consumption (COD), anionic surfactants (APAS), total iron, and manganese (Decree of the Government of the Republic of Kazakhstan No. 209, 2015).

The microbiological examination of water determined the total microbial number (the number of microorganisms in $1 \mathrm{ml}$ ), the number of fungi and actinomycites, colonies of blue-green algae. The total microbial count (TBC) - the number of mesophilic aerobic and optional anaerobic bacteria in $1 \mathrm{~cm}^{3} / \mathrm{ml}$ of water - is determined in all types of water. The result (TBC) is calculated by summing the arithmetic mean number of bacteria, yeast and mold fungi and expressed in colony forming units (CFU / $\mathrm{ml}$ ). Water is considered of good quality if the number of microorganisms is less than 100 per $1 \mathrm{ml}$ of water. In order to calculate the total number of microorganisms in a sample of water for planting in a nutrient medium, dilutions at different concentrations are used. The results are obtained in 3-4 days (Howle et al., 1997). The results of the experiments are statistically processed by student's criterion (Zaitsev, 1981).

\section{RESULTS AND DISCUSSION}

The results of hydrochemical studies of groundwater and the central water supply used for drinking and economic activities of the Kievka village are given in Tables 2 and 3.

As a result of the hydrochemical studies of drinking water, $\mathrm{pH}$, suspended solids, chlorides, sulfates, phosphates, ammonium nitrogen,

Table 1. Water sampling points

\begin{tabular}{|c|l|l|}
\hline $\begin{array}{c}\text { No. } \\
\text { points }\end{array}$ & \multicolumn{1}{|c|}{ Type of water use } & \\
\hline 1 & Process water & Autonomous school well \\
\hline 2 & Underground drinking water & Street column in the west of Kievka village \\
\hline 3 & Drinking water central water supply & Kiev secondary school №3 \\
\hline 4 & Drinking water central water supply & Kindergarten Altyn-dan \\
\hline 5 & Drinking water & Column near the school east side, at the beginning of the center water supply \\
\hline 6 & Drinking water & Column near the school of the western side, at the end of the center water supply \\
\hline
\end{tabular}


Table 2. Hydrochemical studies of drinking water of Kievka village

\begin{tabular}{|c|c|c|c|c|c|}
\hline \multirow{4}{*}{$\begin{array}{l}\text { Name of the defined } \\
\text { indicator }\end{array}$} & \multirow{4}{*}{$\begin{array}{c}\text { Unit of } \\
\text { measurement }\end{array}$} & \multirow{4}{*}{ MPC } & \multicolumn{3}{|c|}{ Actual value } \\
\hline & & & \multicolumn{3}{|c|}{ Sample ID / Sampling Point Name } \\
\hline & & & 172ТВ-1 & 172ТВ-2 & 172B-4 \\
\hline & & & $\begin{array}{l}\text { Kindergarten } \\
\text { Altyn-dan }\end{array}$ & $\begin{array}{c}\text { Kiev secondary school } \\
\text { №3 }\end{array}$ & $\begin{array}{l}\text { Street column in the west } \\
\text { of the village, where the } \\
\text { beginning of the route }\end{array}$ \\
\hline 1 & 2 & 3 & 4 & 5 & 7 \\
\hline $\mathrm{pH}$ & - & $6-9$ & 7,71 & 7,73 & 7,53 \\
\hline Suspended substances & $\mathrm{mg} / \mathrm{dm}^{3}$ & - & 6 & 5 & $<5,0$ \\
\hline Dry residue & $\mathrm{mg} / \mathrm{dm}^{3}$ & 1000 & 2900 & 1920 & 589 \\
\hline Chlorides & $\mathrm{mg} / \mathrm{dm}^{3}$ & 350 & 176,56 & 192,16 & 216,26 \\
\hline Sulfates & $\mathrm{mg} / \mathrm{dm}^{3}$ & 500 & 11,39 & 12,69 & 189,75 \\
\hline Phosphates & $\mathrm{mg} / \mathrm{dm}^{3}$ & 3,5 & 1,914 & 0,961 & 0,599 \\
\hline Total hardness & mg-eq/dm ${ }^{3}$ & 7,0 & 13,2 & 13,8 & 8,93 \\
\hline Sodium & $\mathrm{mg} / \mathrm{dm}^{3}$ & 200 & 126,53 & 123,8 & 131,99 \\
\hline Ammonia nitrogen & $\mathrm{mg} / \mathrm{dm}^{3}$ & 2,0 & $<0,05$ & $<0,05$ & $<0,05$ \\
\hline Nitrites & $\mathrm{mg} / \mathrm{dm}^{3}$ & 3,0 & $<0,002$ & $<0,002$ & $<0,006$ \\
\hline Nitrates & $\mathrm{mg} / \mathrm{dm}^{3}$ & 45 & 0,301 & 0,416 & 0,372 \\
\hline COD & $\mathrm{mg} / \mathrm{dm}^{3}$ & 30 & $<5$ & $<5$ & 6,4 \\
\hline APAV & $\mathrm{mg} / \mathrm{dm}^{3}$ & 0,5 & $<0,025$ & 0,028 & 0,057 \\
\hline Common iron & $\mathrm{mg} / \mathrm{dm}^{3}$ & 0,3 & 0,112 & $<0,1$ & 0,180 \\
\hline Manganese & $\mathrm{mg} / \mathrm{dm}^{3}$ & 0,1 & $<0,002$ & $<0,002$ & 0,0037 \\
\hline
\end{tabular}

Table 3. Hydrochemical studies of industrial water

\begin{tabular}{|c|c|c|}
\hline \multirow{4}{*}{ Name of the defined indicator } & \multirow{4}{*}{ Unit of measurement } & Actual value \\
\hline & & Sample ID / Sampling Point Name \\
\hline & & 172B-3 \\
\hline & & Autonomous school well \\
\hline 1 & 2 & 6 \\
\hline $\mathrm{pH}$ & - & 7,43 \\
\hline Electrical conductivity & $\mathrm{ms} / \mathrm{cm}$ & 1889 \\
\hline Suspended substances & $\mathrm{mg} / \mathrm{dm}^{3}$ & 12 \\
\hline Dry residue & $\mathrm{mg} / \mathrm{dm}^{3}$ & 944 \\
\hline Chlorides & $\mathrm{mg} / \mathrm{dm}^{3}$ & 271,57 \\
\hline Sulfates & $\mathrm{mg} / \mathrm{dm} 3$ & 311,58 \\
\hline Phosphates & $\mathrm{mg} / \mathrm{dm} 3$ & 0,899 \\
\hline Total hardness & $\mathrm{mg}$-eqv/dm ${ }^{3}$ & 16,95 \\
\hline Sodium & $\mathrm{mg} / \mathrm{dm}^{3}$ & 205,67 \\
\hline Ammonia nitrogen & $\mathrm{mg} / \mathrm{dm}^{3}$ & $<0,05$ \\
\hline Nitrites & $\mathrm{mg} / \mathrm{dm}^{3}$ & $<0,006$ \\
\hline Nitrates & $\mathrm{mg} / \mathrm{dm}^{3}$ & 0,350 \\
\hline COD & $\mathrm{mg} / \mathrm{dm}^{3}$ & 12,25 \\
\hline APAV & $\mathrm{mg} / \mathrm{dm}^{3}$ & 0,078 \\
\hline Common iron & $\mathrm{mg} / \mathrm{dm}^{3}$ & 0,233 \\
\hline Manganese & $\mathrm{mg} / \mathrm{dm}^{3}$ & 0,0023 \\
\hline
\end{tabular}


Table 4. Indicators of the total microbial number of groundwater and water of the central water supply of the village Kievka

\begin{tabular}{|c|c|c|c|}
\hline \multirow{2}{*}{ № points } & \multirow{2}{*}{$1 / \mathrm{ml}$} & $\chi^{10^{-4}}$ & $\chi^{10^{-5}}$ \\
\cline { 1 - 3 } CFU / ml & $233,67 \pm 17,65.10^{2}$ & $41,33 \pm 7,42.10^{5}$ & $31,33 \pm 6,46.10^{6}$ \\
\hline \multirow{2yyn}{*}{ №5 } & $133,33 \pm 13,13.10^{2}$ & $74 \pm 9.93 .10^{5}$ & $23,33 \pm 5,58.10^{6}$ \\
\hline \multirow{2}{*}{ №6 } & $\infty \infty \infty$ & $146 \pm 13,96.10^{5}$ & $55 \pm 8,49.10^{6}$ \\
\hline \multirow{2}{*}{ №3 } & $182,67 \pm 15,61.10^{2}$ & $154 \pm 14,33.10^{5}$ & $34,33 \pm 6,77.10^{6}$ \\
\hline
\end{tabular}

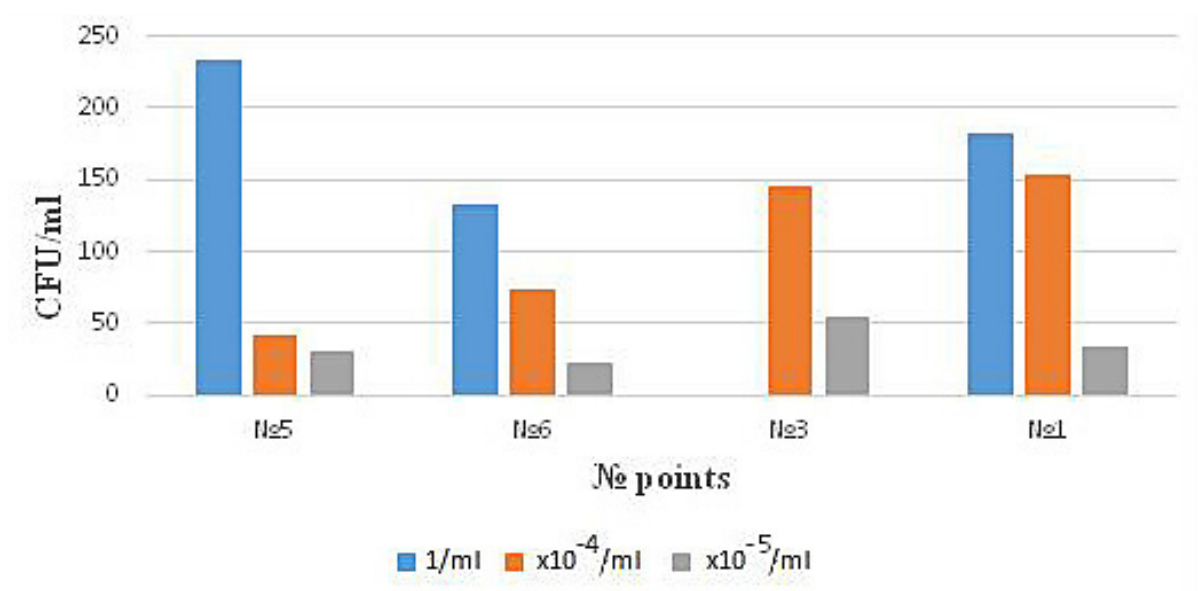

Figure 1. Indicators of the total microbial number of groundwater and the water of central water supply Kievka river

nitrites, nitrates, COD, anionic surfactants, total iron, and manganese do not exceed the MPC in all samples. The total hardness at all 3 points exceeds the MPC: at 5 points $-13.2 \mathrm{mg} / \mathrm{dm}^{3}$, at 3 points $-13.8 \mathrm{mg} / \mathrm{dm}^{3}$, at 2 points $-8.93 \mathrm{mg} / \mathrm{dm}^{3}$, dry residue exceeds 4 points $-2900 \mathrm{mg} / \mathrm{dm}^{3}$ and at 3 points $-1920 \mathrm{mg} / \mathrm{dm}^{3}$.

According to the hydrochemical indicators, the technical water of an autonomous school well contains chlorides, sulfates, phosphates, ammonium nitrogen, nitrites, nitrates, total iron, and manganese. All indicators are within the norm.

According to the results of the hydrobiological studies of the samples from four sampling points, it is shown that all samples are positive in terms of the total microbial number (see Table 4).

According to the analysis of research results, it can be noted that a large number of CFUs were observed in the sample No. 1 and the sample No. 3, for example, in a sample concentration of $10-4 / \mathrm{ml}$ in the sample No. 3 there were $146 \pm 13.96 .105 \mathrm{CFU} / \mathrm{ml}$. At the initial concentration ( $1 \mathrm{ml}$ of the sample) the sample No. 5 was $233.67 \pm 17.65 .102$, while the sample No. 1 reached $182.67 \pm 15.61 .102 \mathrm{CFU} / \mathrm{ml}$ (Figure 1).

While studying the colonies grown on different samples, the following results were obtained. In sample 5, the colonies are separated, the color of the colony is yellow, the shapes are spherical and transparent (see Figure 2).

In the water samples in which $1 \mathrm{ml}$ of the sample was taken without dilution, both red and yellow colonies of microorganisms were observed.

The colonies of the sample No. 6 of different colors: yellow, pink, light yellow and purple. Some small-sized colonies are spread over the entire surface (see Figure 3).

The sample No. 3 colonies are transparent or yellow, and there are also light opaque types of microorganisms (see Figure 4). 
2)

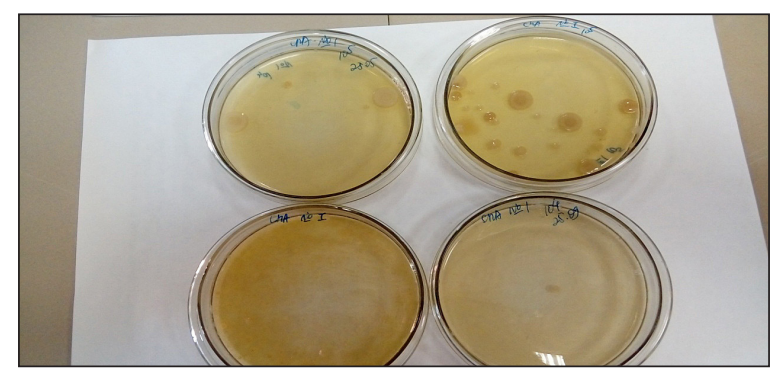

2b)

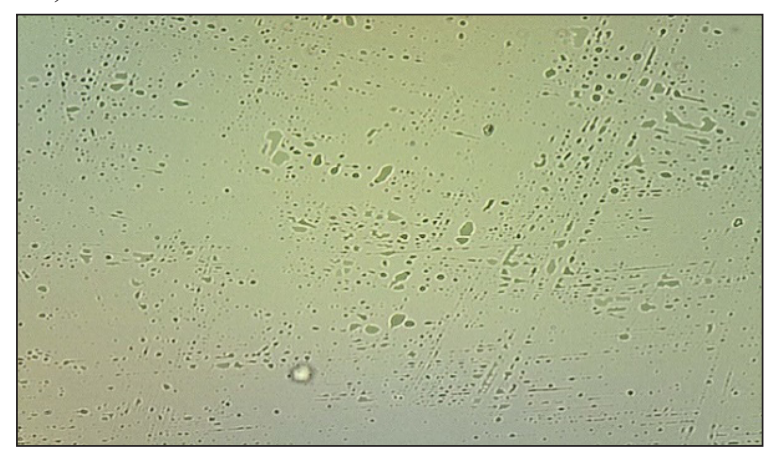

2d)

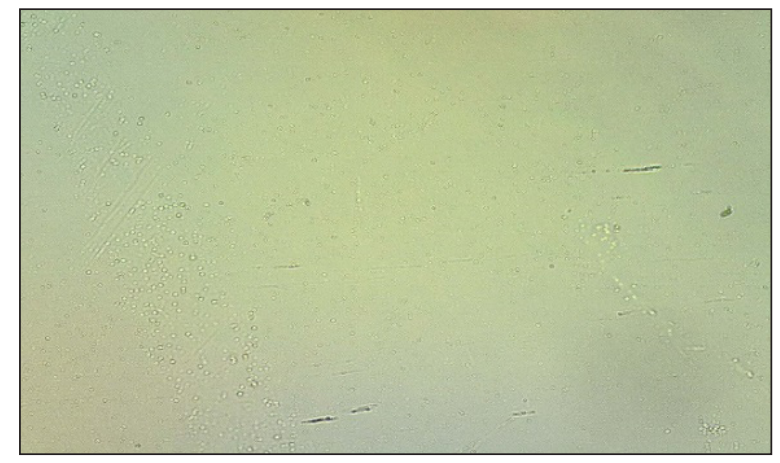

2a)

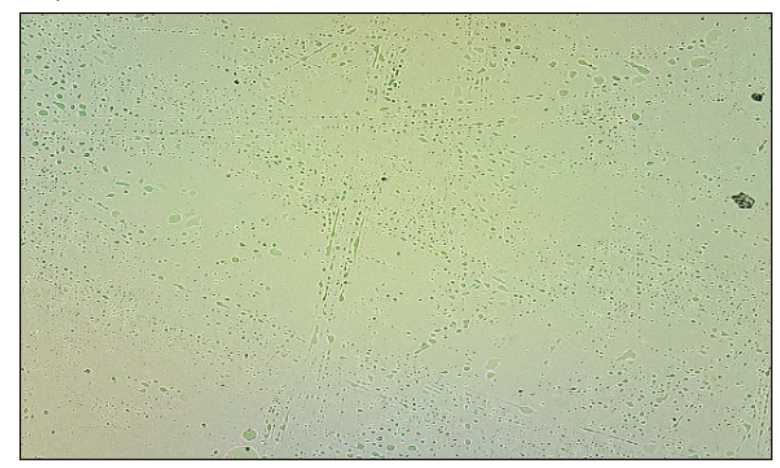

2c)

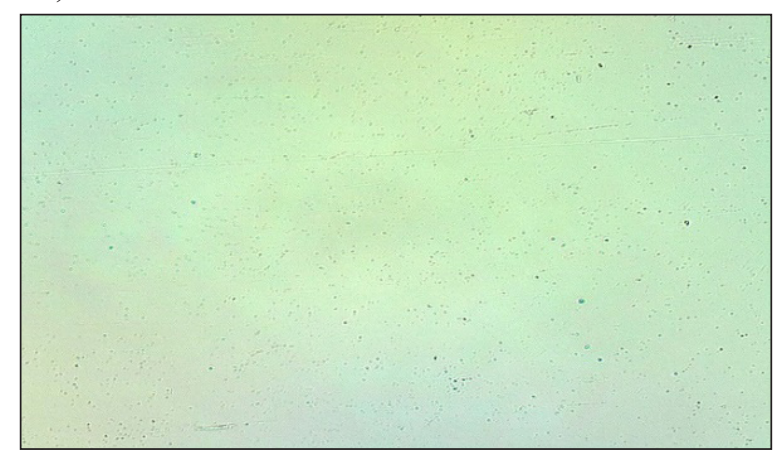

2e)

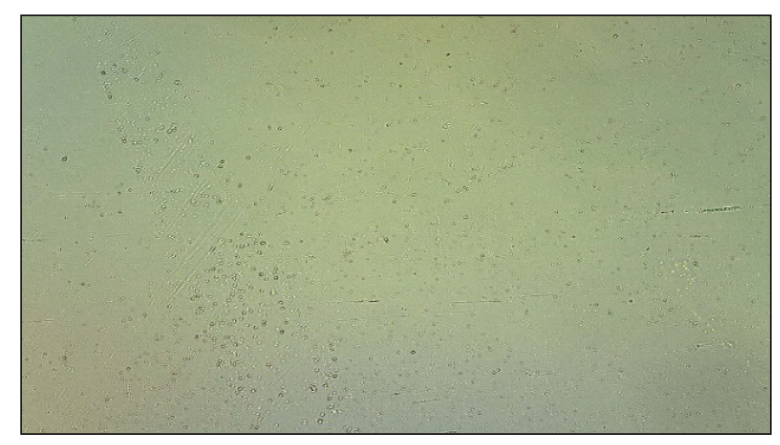

Figure 2 Colonies of water No. 5 of sample:

a), b) - original concentration,

c) $102 \mathrm{COE} / \mathrm{ml}$, d) $103 \mathrm{CFU} / \mathrm{ml}$, e) $104 \mathrm{CFU} / \mathrm{ml}$

The samples of water No. 1 are small, yellowish and transparent, some colonies are large, light, transparent (see Figure 5).

According to the results of calculating the number of fungi, including actinomycetes, it can be noted that they are present in all samples (see Table 5).

In all samples, an endless growth of fungi was observed in an amount of $1 \mathrm{ml}$ of water. The results of the calculation pertaining to the number of fungi showed that at the point No. 1 the largest number of fungi $46 \pm 7.83 .104$ was observed at concentrations of $10-3 / \mathrm{ml}$ (see Figure 6).
While calculating the number of actinomycetes showed growth in $1 \mathrm{ml}$ of the sample, an endless growth was observed in the sample No. 3, with the largest amount obtained at a concentration of $10-3 / \mathrm{ml}$ (see Figure 7a, 7b).

Figure 8 shows the growth of fungi and actinomycetes in all water samples taken for analysis from the Kievka village.

In the samples of all waters at the initial concentration, infinite growth of fungi was observed, and the actinomycetes in sample No. 1 was higher than the others, which is $29.33 \pm 6.25 .102 / \mathrm{ml}$. When the concentration of 
3)

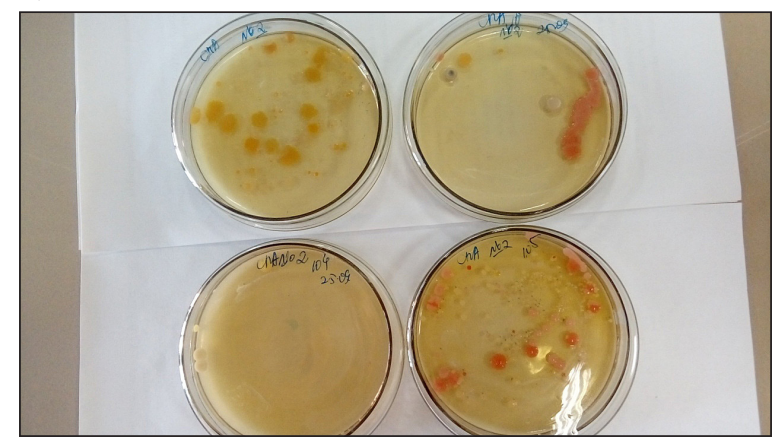

$3 b)$

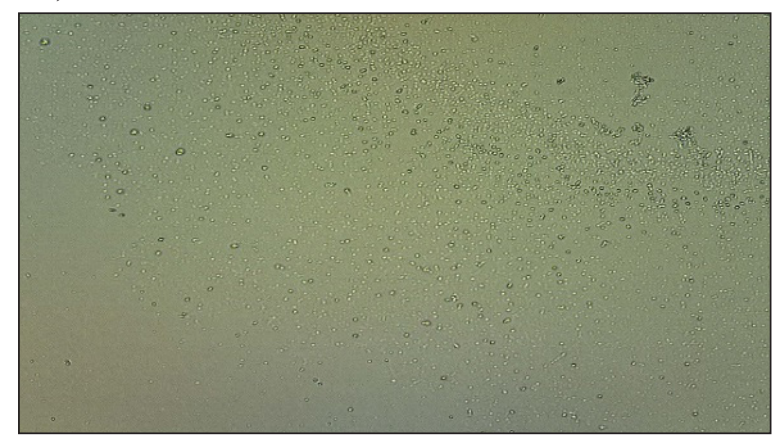

3a)

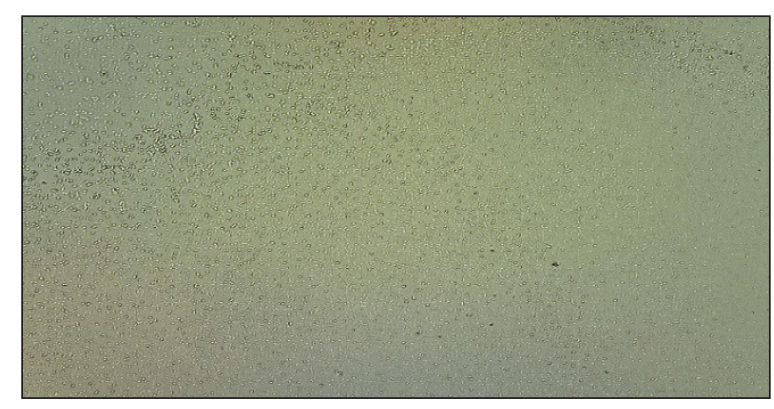

$3 c)$

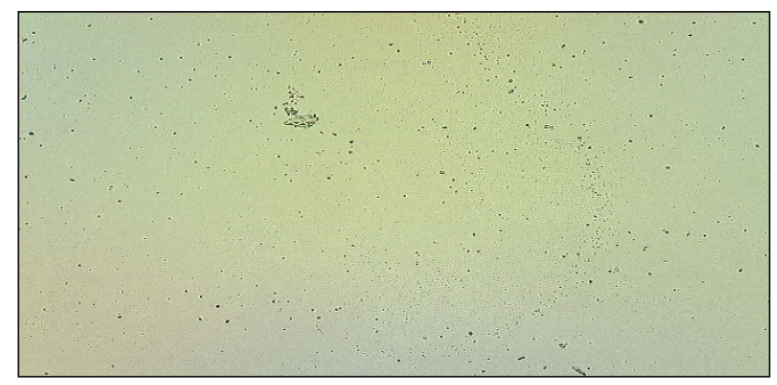

$3 d)$

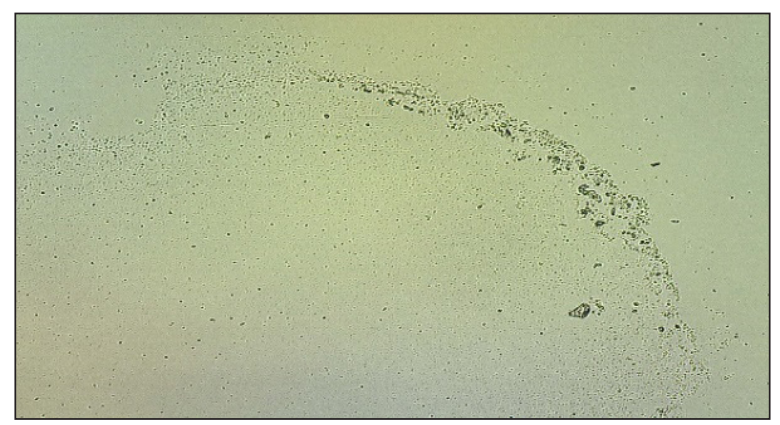

Figure 3. Colonies of water in the sample No. 6: a) the initial concentration,

b) initial concentration, c) $102 \mathrm{KOE} / \mathrm{ml}$, d) $102 \mathrm{CFU} / \mathrm{ml}$

the sample is $102 / \mathrm{ml}$, there are more fungi in the sample No. 1, actinomycetes in the sample No. 3, while the sample concentration is $103 / \mathrm{ml}$, in the sample No. 1, actinomycetes in the sample No. 3, which is $46 \pm 7.83 .104 / \mathrm{ml}$.

\section{CONCLUSION}

While assessing the hydrochemical state of drinking water in the village of Kievka, it can be noted that the dry residue exceeds the maximum allowable concentration in the "Altyn-dan" kindergarten $-2900 \mathrm{mg} / \mathrm{dm}^{3} ; 13.2 \mathrm{mg} / \mathrm{dm}^{3}$ showed a hardness in kindergarten, $13.8 \mathrm{mg} / \mathrm{dm}^{3}$ at school, and a street column in the west of the village, where the start of the route was $8.93 \mathrm{mg} / \mathrm{dm}^{3}$. In the autonomous school well, the highest electrical conductivity is $1889 \mathrm{~ms} / \mathrm{cm}$, chlorides $-271.57 \mathrm{mg} / \mathrm{dm}^{3}$, sulfates $311.58 \mathrm{mg} / \mathrm{dm}^{3}$, total hardness $16.95 \mathrm{mg} / \mathrm{dm}^{3}$, sodium $-205.67 \mathrm{mg} / \mathrm{dm}^{3}$.

As a result of the microbiological studies of the water samples from the village of Kievka, the following were revealed: TBC of underground water and water of the central water supply in sample No. 5 at the initial concentration of $233.67 \pm$ 17.65.102 CFU $/ \mathrm{ml}$ : at a concentration of $10-4 / \mathrm{ml}$ TBC $41.33 \pm 7,42.105 \mathrm{CFU} / \mathrm{ml}$, No. 6 at the initial concentration $133.33 \pm 13.13 .102 \mathrm{CFU} / \mathrm{ml}$, at the No. 3 sample at $10-4 / \mathrm{ml}$ concentration $146 \pm 13.96 .105 \mathrm{CFU} / \mathrm{ml}, 10-5 / \mathrm{ml}$ concentration $55 \pm 8.49 .106 \mathrm{CFU} / \mathrm{ml}$, in No. 1 sample at the initial concentration of $182.67 \pm 15.61 .102 \mathrm{CFU} / \mathrm{ml}$, $10-4 / \mathrm{ml}$ of concentration $154 \pm 14.33 .105 \mathrm{CFU} / \mathrm{ml}$. 
4)

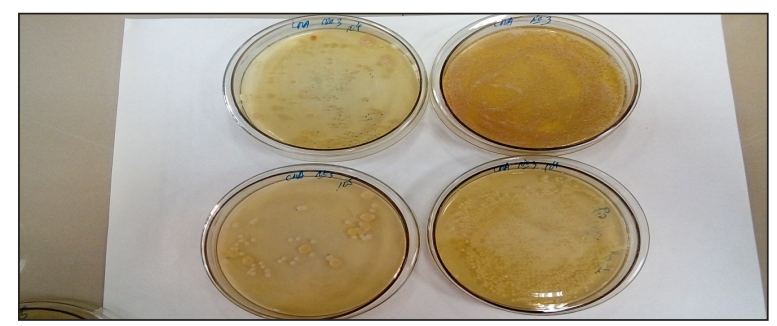

$4 b)$

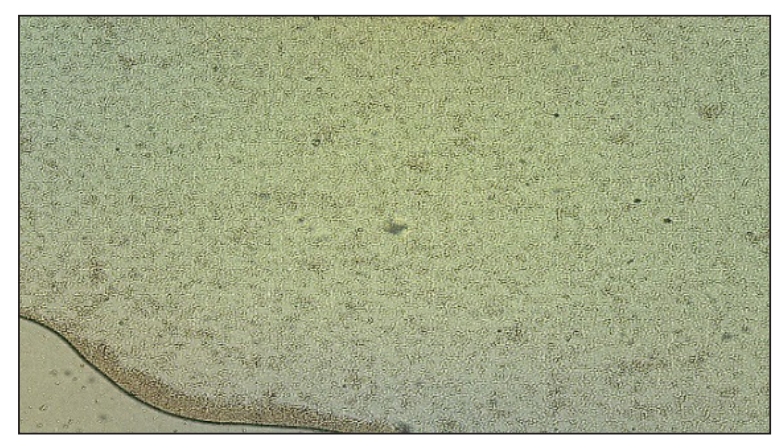

4a)

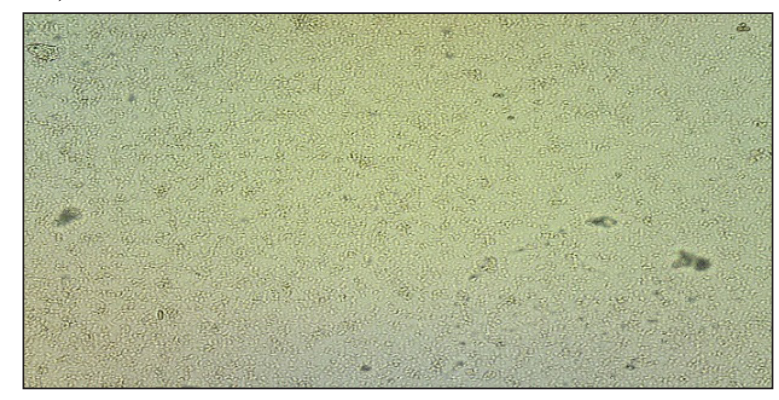

$4 c)$

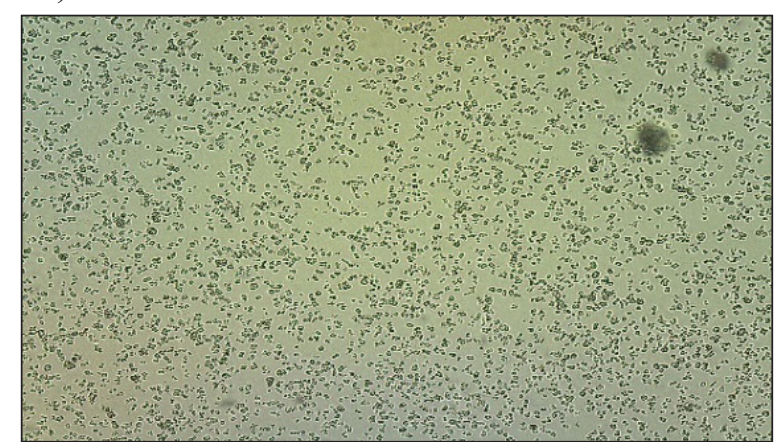

Figure 4. Colonies of the water sample No. 3: a) initial concentration, b) $1010 \mathrm{CFU} / \mathrm{ml}$, c) initial concentration 5a)

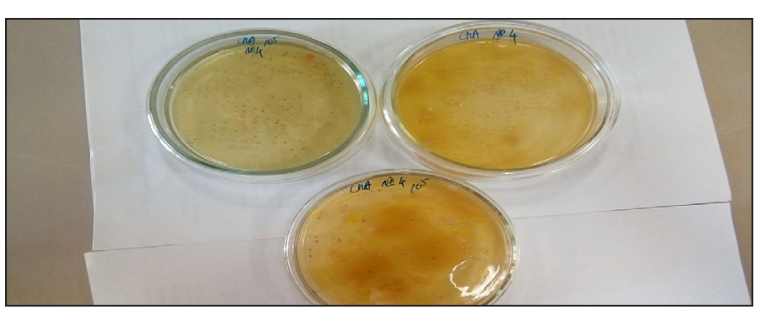

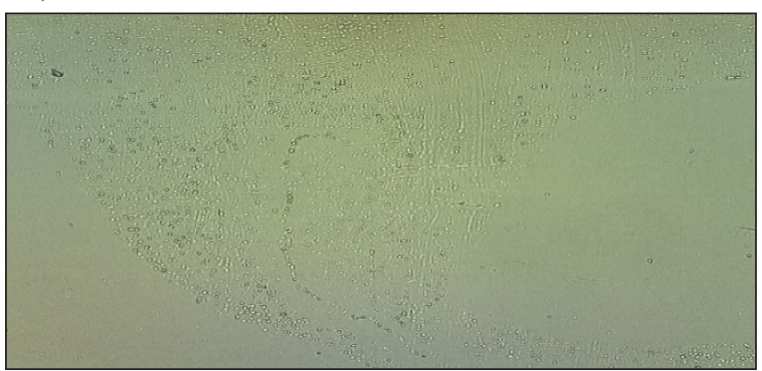

$5 b)$

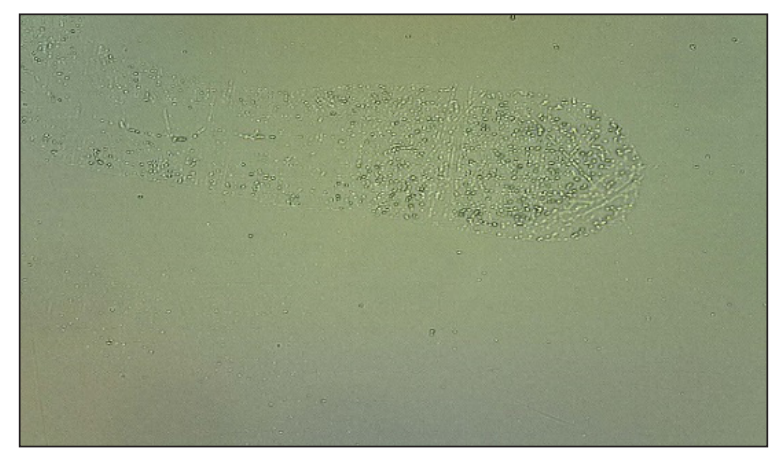

Figure 5. Colonies of water \# 1 of sample: a), b) - initial concentration

\section{REFERENCES}

1. Brindha, K., Pavelic, P., Sotoukee, T., Douangsavanh, S. \& Elango, L. 2017. Geochemical characteristics and groundwater quality in the Vientiane Plain, Laos Expo. Health, 9, 89-104.

2. Decree of the Government of the Republic of
Kazakhstan No. 209 (2015). Sanitary rules "Sanitary and epidemiological requirements for water sources, water intake sites for household and drinking purposes, household water supply and places for cultural and community water use and safety of water bodies".

3. Howle, J., Krieg, N., Snita, P., Staley, J. \& Williams, S. 1997. The determinant of bacteria Burgi. 
Table 5. The number of fungi and actinomycetes in the water samples of the village

\begin{tabular}{|c|l|c|c|c|}
\hline \multicolumn{2}{|c|}{ № points } & $1 / \mathrm{ml}$ & $\chi^{10^{-2} / \mathrm{ml}}$ & $\chi^{10^{-3} / \mathrm{ml}}$ \\
\hline \multirow{2}{*}{ № 5 } & Fungi & $\infty \infty \infty \infty$ & $5 \pm 2,58.10^{3}$ & $4,67 \pm 2.50 .10^{4}$ \\
\cline { 2 - 5 } & Actinomycetes & $23,67 \pm 5.62 .10^{2}$ & $17.33 \pm 4.81 .10^{3}$ & $2,0 \pm 1.63 .10^{4}$ \\
\hline \multirow{2}{*}{ № 6 } & Fungi & $\infty \infty_{\infty}$ & $6.0 \pm 2,83.10^{3}$ & $4,0 \pm 2.31 .10^{4}$ \\
\cline { 2 - 5 } & Actinomycetes & $15.0 \pm 4.47 .10^{2}$ & $7.67 \pm 3.20 .10^{3}$ & $5,0 \pm 2,58.10^{4}$ \\
\hline \multirow{2}{*}{ № 3 } & Fungi & $\infty \infty \infty$ & $6.0 \pm 2,83.10^{3}$ & $7,0 \pm 3.05 .10^{4}$ \\
\cline { 2 - 5 } & Actinomycetes & $\infty \infty \infty$ & $25.67 \pm 5.85 .10^{3}$ & $46 \pm 7.83 .10^{4}$ \\
\hline \multirow{2}{*}{ № 1 } & Fungi & $\infty \infty \infty$ & $6,67 \pm 2,98.10^{3}$ & $14.67 \pm 4.42 .10^{4}$ \\
\cline { 2 - 5 } & Actinomycetes & $29,33 \pm 6.25 .10^{2}$ & $6.0 \pm 2,83.10^{3}$ & $7.0 \pm 3.05 .10^{4}$ \\
\hline
\end{tabular}

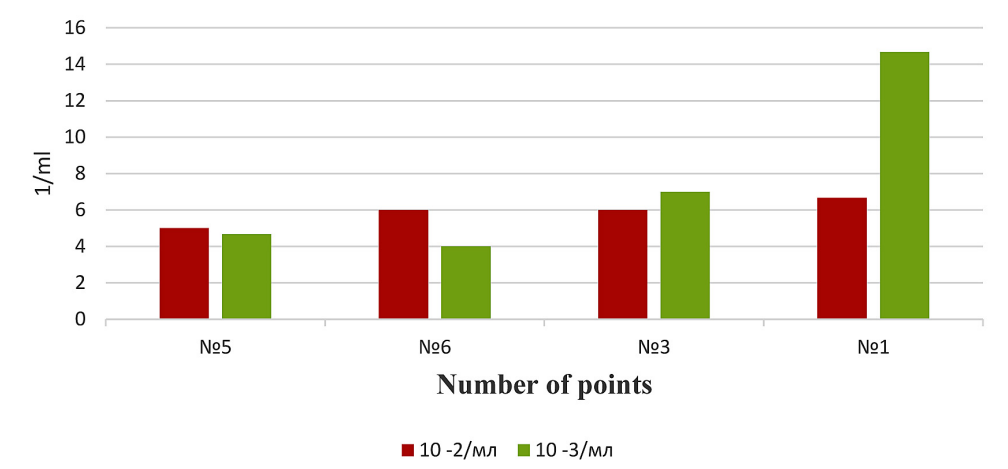

Figure 6. The results of the calculation of the number of mushrooms

a)

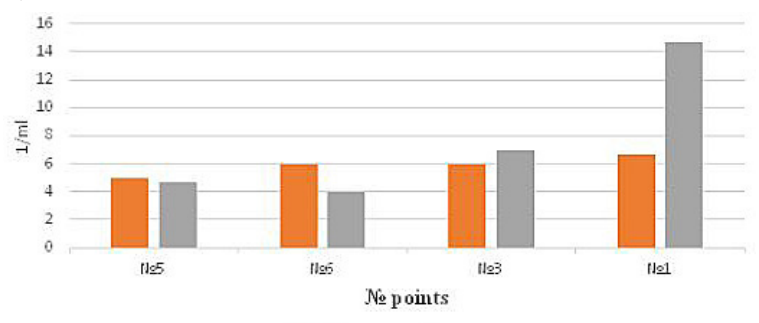

$m 10^{-2} / \mathrm{ml} 1 \mathrm{n10^{-3 } / \mathrm { ml }}$ b)

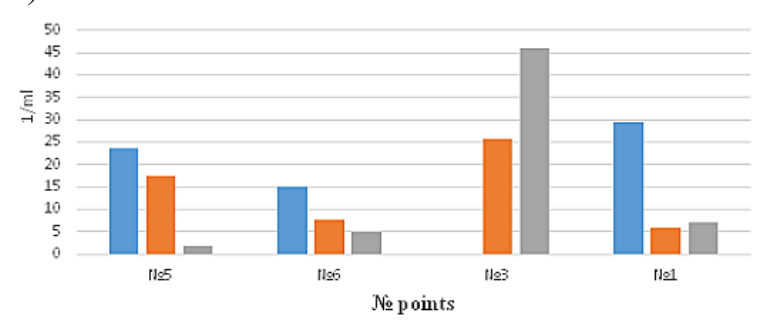

미 $1 / \mathrm{ml}=10^{-2} / \mathrm{ml} \quad \square 10^{-3} / \mathrm{ml}$

Figure 7. a) b) results of calculating the amount of actinomycetes

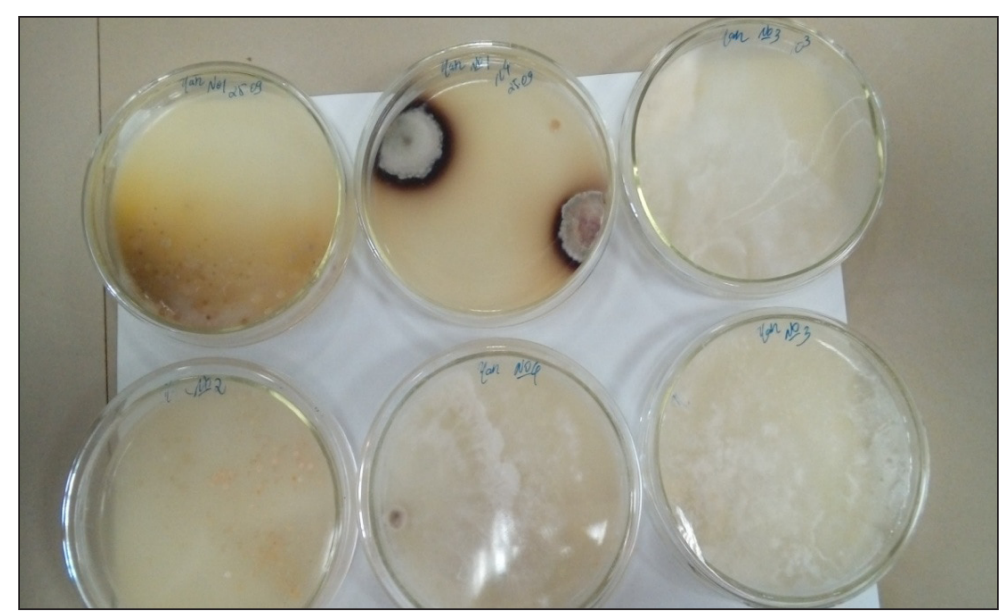

Figure 8. The growth of fungi and actinomycetes in all water samples taken for analysis from the Kievka village 
Moscow: Mir.

4. Konikow, L.F. \& Kendy, E. 2005. Groundwater depletion: a global problem. Hydrogeological Journal, 13(1), 317-320

5. Kumar, M., Ramanathan, A.L., Tripathi, R., Farswan, S., Kumar, D. \& Bhattacharya, P. 2017. A study of trace element contamination using multivariate statistical techniques and health risk assessment in groundwater of Chhaprola Industrial Area, Gautama Buddha Nagar, Uttar Pradesh, India. Chemosphere, 166, 135-145.

6. Mukherjee, A., Bhattacharya, P., Savage, K., Foster, A. \& Bundschuh, J. 2008. Distribution of geogenic arsenic in hydrologic systems: controls and challenges. Journal of Contaminant Hydrology, 99(1), 1-7.

7. Raju, N.J., Ram, P. \& Dey, S. 2009. Groundwater quality in the lower Varuna River basin, Varanasi district, Uttar Pradesh. Journal of the Geological Society of India, 173, 178.

8. Scanlon, B.R., Reedy, R.C. \& Tachovsky, J.A. 2007.
Semiarid unsaturated zone chloride profiles: archives of past land use change impacts on water resources in the southern High Plains, United States. Water Resources Research, 43(6). https:// doi.org/10.1029/2006WR005769

9. Shiklomanov, I.A. 2000. Appraisal and assessment of world water resources. Water International, 25 (1), 11-32.

10. Singh, A.K., Tewary, B. \& Sinha, A. 2011. Hydrochemistry and quality assessment of groundwater in part of NOIDA metropolitan city, Uttar Pradesh. Journal of the Geological Society of India, 78 (6), 523-540.

11. Yadav, I.C., Singh, S., Devi, N.L., Mohan, D., Pahari, M., Tater, P.S. \& Shakya, B.M. 2012. Spatial distribution of arsenic in groundwater of Southern Nepal. Reviews of Environmental Contamination and Toxicology, 218, 125-140.

12. Zaitsev, G.N. 1981. Mathematical analysis of biological data. Moscow: Science. 